Marion Stange

\title{
3. Defining a Nation: Patriotic Associations, 1774-1776
}

The majority of historians dealing with the American Revolutionary era are convinced that a common American identity did not evolve until after the founding of the United States of America. ${ }^{1}$ But does this judgment hold true? Do not the joint efforts of the North American colonists during the American Revolution prove that there already existed a strong feeling of belonging together, a feeling of common identity? Or was this union merely a means to an end propagated by the colonial elite in order to secure its interests, but lacking any kind of foundation within the colonial population? The patriotic associations formed between 1774 and 1776 provide important information regarding these questions. So far, they have not been objects of great interest among American historians. This neglect is astonishing considering the vital role the associations played in organizing the patriots' resistance against Great Britain. They not only absorbed the opinions and sentiments prevalent in the colonies between 1774 and 1776, but also served as mainsprings of the revolutionary movement by mobilizing as many colonists as possible for the Common Cause.

Like no other documents, the associations ${ }^{2}$ reflect the development of the colonists' political positions in the crucial time period between 1774 and 1776. By analyzing the language used in the different associations in the course of these two years it is possible to reconstruct the very beginnings of the revolutionary process that eventually led to the founding of the United States of America. The main point of interest in this context is in which way the colonists' self-perception as well as the perception and presentation of their adversaries changed between 1774 and 1776.

\footnotetext{
${ }^{1}$ See for instance Jack P. GREENE, Understanding the American Revolution. Issues and Actors. Charlottesville/London 1995, p. 139; Elise MARIENSTRAS, Nationality and Citizenship. In: Jack P. GreENE and Jack R. POLE (eds.), The Blackwell's Companion to the American Revolution. Oxford/Malden, MA 2000, p. 680-685, p. 680; Michael ZuCKERMAN, Identity in British America : Unease in Eden. In: Nicholas CANNY and Anthony Pagden (eds.), Colonial Identity in the Atlantic World. Princeton, NJ/Guildford 1987, p. 115-157.

2 Subsequently, the word "association" will be used as a synonym not only for the group of people who associated, but also for the document the associators subscribed to.
} 


\section{Definition}

The term "association" has not changed significantly in the course of the last centuries. Modern as well as eighteenth-century dictionaries and encyclopedias describe associations as unions of one or more persons who pursue a common goal and attempt to achieve it by joint efforts. ${ }^{3}$ However, twentieth-century reference works distinguish between the association as a group of people with similar interests and the association as a document that fixed the common objectives in writing and was signed by the associators. ${ }^{4}$ In contrast, the contemporary understanding of the word during the time of the American Revolution implied a natural connection of the two meanings, and put a particular stress on the contract character of such agreements:

\section{"Association is properly a contract or treaty of partnership, whereby two or more persons unite together, either for their mutual assistance, or for the joint carrying of an affair..."}

This definition implies that there are two important factors that characterize associations: First, there have to be at least two persons who subscribe to the association, and second, these persons have to agree on a common course of action. Although the associations varied considerably regarding their structure and wording, all of them contained the formulation "we...associate [also: engage; covenant; promise; agree; entered into the following Resolution and Association...]" as well as the signatures of the associators. It is important to underline these features in order to be able to distinguish associations from similar documents like addresses to the king or governor, oaths of allegiance or tests. ${ }^{6}$

\section{Distributing the Associations}

In order to ensure the effectiveness of associations as a means of putting pressure on Great Britain, the patriots tried to win as many colonists as possible to their side. They

\footnotetext{
3 Thomas Dobson (ed.): Encyclopædia; or a Dictionary of Arts, Sciences and Miscellaneous Literature. Bd. 2. Philadelphia 1798, S. 406, "Associationc; E. ChAmbers (ed.), Cyclopedia: Or, an Universal Dictionary of Arts and Sciences, vol. 1. London 1786, "Association"; James A. H. MurRAY et al. (eds.), OED - The Oxford English Dictionary, vol. 1. Oxford 1933, p. 513-514.

${ }^{4}$ Murray et al. (eds.), OED - The Oxford English Dictionary, vol. 1, p. 513-514.

${ }^{5}$ CHAMBers (ed.), Cyclopedia, vol. 1, „Association”.

${ }^{6}$ In their addresses to the king or the respective colony's governor, the colonists usually just stated their opinions and points of view. With their signature the authors of such documents did not commit themselves to any course of action as it was the case with the associations. Tests and oaths of allegiance were of a similarly obliging nature as the associations. Tests were pledges of loyalty which the patriotic legislative organs demanded of their members. The signatories usually agreed to accept the regulations of the Provincial and Continental Congresses. Oaths of allegiance gained importance only after the escalation of the military struggle with Great Britain, especially after the Declaration of Independence. The commitment contained in these documents did not refer to a group of people who had united for the purpose of achieving one common goal, as it was the case in the associations, but was limited to just one person who pledged his or her loyalty either to the British or the new government of the United States of America.
} 
had to provide for a system of distribution that would enable every colonist in every little town even in the rural counties to sign the associations and participate in the resistance movement. Since there was no central authority that could do this effectively, the distribution was delegated to local institutions. Copies of the associations were produced to provide delegates and institutions with them. Apart from these official samples, the documents were also printed as broadsides and published in the colonial newspapers. In order to address as many colonists as possible, broadsides were produced in relatively large numbers, often amounting to several thousand copies. ${ }^{7}$ In some colonies, the documents were even translated into other languages. This way, the patriots made sure that the resistance movement also covered the non-Englishspeaking parts of the colonial population. ${ }^{8}$

The committee-system that was established by the Continental Association played a vital role regarding the distribution of the associations. After the eleventh article of the Continental Association had determined the colonists' obligation to choose committees of inspection and observation in every county, city, and town to enforce the articles of the Continental Congress, ${ }^{9}$ other associations also used these committees for the distribution of their documents. For instance, after the New York Provincial Congress had entered into an association in April 1775, it sent copies of the document to all of the eleven counties of the colony which in turn forwarded the association to all the local committees. It was the committees' duty to publish the measures in their respective jurisdictions and to give the inhabitants a chance to subscribe to the agreement. Subsequently, the committees listed associators and non-associators and sent the names to the Provincial Congress. ${ }^{10}$

The group of persons that was allowed to subscribe to the patriotic agreements varied largely from association to association. In most cases it comprised all white males that were 21 years and older. ${ }^{11}$ Thus, apart from freeholders and freemen who, because of their property, were qualified to vote in regular elections as well, it also included the simple inhabitants who did not own any real estate or other property. There were exceptions, however. The Boston Covenant, founded in June 1774, ad-

\footnotetext{
7 See Robert L. SCRIBNER (ed.), Revolutionary Virginia. The Road to Independence, vol. 1: Forming Thunderclouds and the first Convention, 1763-1774. A Documentary Record. Ser. 1. 1973, p. 231.

${ }^{8}$ For instance, the Pennsylvania committee of safety published its Articles of Association also in Dutch language. See AA, $4^{\text {th }}$ Ser., vol. 3, p. 859-862.

${ }_{9}$ See AA, $4^{\text {th }}$ Ser., vol. 1, p. 913-916.

${ }^{10}$ See AA, $4^{\text {th }}$ Ser., vol. 3, p. 581-620. Further illustrations of this practice of distributing the association documents can be found in the following documents: AA, $4^{\text {th }}$ Ser., vol. 2, p. 690; AA, $4^{\text {th }}$ Ser., vol. 4, p. 755-757.

11 See AA, 4th Ser., vol. 1, p. 1136-1137; AA, 4th Ser., vol. 1, p. 1145-1146; AA, 4th Ser., vol. 3, p. 681-620; AA, $4^{\text {th }}$ Ser., vol. 2, p. 505; AA, $4^{\text {th }}$ Ser., vol. 2, p. 615-616; AA, $4^{\text {th }}$ Ser., vol. 2, p. 690; AA, $4^{\text {th }}$ Ser., vol. 2, p. 897; William L. SAUNDERS (ed.): Colonial Records of North Carolina, vol. 10. New York 1968 (Repr. of the ed. Raleigh, N.C. 1886-1890), p. 61-62; AA, $4^{\text {th }}$ Ser., vol. 2, p. 1551-1552; AA, $4^{\text {th }}$ Ser., vol. 3, p. 99100; AA, $4^{\text {th }}$ Ser., vol. 3, p. 1026-1027; AA, 4th Ser., vol. 4, p. 858; AA, 4th Ser., vol. 5, p. 873-912.
} 
dressed all "adult persons of both sexes"12. There are no other examples of such an explicit inclusion of female colonists into the group of associators, but in some cases associations allowed women who owned real estate to sign the document. ${ }^{13}$ There also were associations that allowed male inhabitants sixteen years and older to subscribe to the measures. ${ }^{14}$

Usually, the different measures and rules of the associations were published during town meetings that were held for this very purpose. After these meetings the colonists had the opportunity to sign the document. Persons who could not attend the town meeting or who did not want to sign immediately were able to sign the document later on, although they had to do so within a certain time-span. To this end, the document was deposited at a central point in town to which the inhabitants had access. For instance, the New York City committee of inspection and observation announced in May 1775 that the New York Association was displayed in a particular house in every single ward where the citizens could go and sign the document. ${ }^{15}$

\section{The Language of Patriotism: Keywords}

Even though the association texts vary in their wording there are certain terms that are used in virtually every document: "liberty" and "property" on the one hand and "honour", "religion" and "virtue" on the other. These concepts formed the basis of the American self-understanding during the American Revolution and have remained key values of American society ever since. By analyzing the associations drafted between 1774 and 1776 one can clearly detect a change in the way these keywords are applied. While, at first, colonists viewed the terms as concepts based on British legal tradition and the British culture, they gradually became explicitly "American" rights and values as the dispute with the mother country intensified.

During the American Revolution the term "liberty" was a keyword in the rhetoric of the American patriots. The patriotic group Sons of Liberty carried the word in their name. The colonists planted "liberty trees" and put up "liberty poles". An indefinite number of poems, ballads and sermons from the 1760s and 1770 s dealt with the concept of liberty. ${ }^{16}$

\footnotetext{
12 AA, 4th Ser., vol. 1, p. 397-398.

13 See David Ammerman, In the Common Cause, American Response to the Coercive Acts of 1774. Charlottesville, VA 1974, p. 118.

14 See AA, 4th Ser., vol. 3, p. 141-143. Another town that also required male inhabitants sixteen years and older to sign up to the association was Acton, Mass. See AmMERMAN, In the Common Cause, p. 118.

${ }^{15}$ See AA, 4th Ser., vol. 2, p. 605.

${ }^{16}$ See Elise Marienstras, Liberty. In: Greene, Pole (eds.), Companion to the American Revolution, p. 627-632, p. 627.
} 
In the associations, this American meaning of liberty was at first of secondary importance. By demanding the protection of their right to liberty, the colonists were simply claiming their rights as subjects of the British crown. "We claim no more than the rights of Englishmen without diminution and abridgment"17, it says in the Association of the North Carolina Convention. The duties and taxes that were raised by Great Britain meant a serious threat to these rights, because the colonists were not represented in the British Parliament. A taxation without representation, the colonists argued, was illegal and "a gross violation of the Grand Charter of our liberties"18. In this context, "liberty" was used as a general term that referred not only to the right to liberty itself, but also included other civil rights like the right to personal safety or the right to property. At this stage, there can hardly be found any trace of a revolutionary, explicitly American meaning of liberty in the associations. In most of the documents written in 1774 and early 1775 the colonists demanded their "constitutional liberty and rights" 19 . Some associations also used the adjectives "ancient"20 and "essential" 21 in this context. This diction shows the colonists' conviction that their demands were founded on a clear legal basis.

When it became obvious that Great Britain would not repeal the acts of Parliament, the tone of voice applied in the associations changed. The patriots no longer used "liberty" as a synonym for the civil rights that all British subjects were entitled to. Especially after the outbreak of hostilities between colonists and British soldiers near Lexington and Concord in April 1775, an explicitly American connotation of the term "liberty" could be found in the documents. Instead of demanding their "constitutional liberties" as they had done before, the colonists used phrases like "rights and liberties of America"22, "preservation of American freedom"23 or "defence of American liberty" 24 more frequently in their later texts.

"American Liberty" became the most important slogan of the patriotic associations. Persons who refused to associate or who violated the rules of the association were considered "Enemies of American Liberty"25. With their attitude, the patriots

\footnotetext{
17 AA, 4th Ser., vol. 1, Sp. 734-737.

18 Ibid.

19 AA, 4th Ser., vol. 1, p. 350-351; AA, 4th Ser., vol. 3, p. 99-100; AA, 4th Ser., vol. 3, p. 1026-1027.

20 AA, 4th Ser., vol. 1, p. 350-351 (“our just, ancient, and constitutional rights”); AA, 4th Ser., vol. 1, p. 1145-1146 ("ancient Laws and Liberty").

21 AA, 4th Ser., vol. 1, p. $734-737$ (“our most essential rights"); AA, 4th Ser., vol. 3, p. 131-132 ("essential securities for the lives, liberties and properties of the subjects").

22 AA, 4th Ser., vol. 3, p. 581-620; AA, 4th Ser., vol. 2, p. 505; SAUNDERS (ed.), Colonial Records of North Carolina, vol. 10, p. 61; AA, 4th Ser., vol. 2, p. 1551-1552; AA, 4th Ser., vol. 3, p. 141-142; AA, 4th Ser., vol. 3, p. 1026-1027.

23 AA, 4th Ser., vol. 2, p. 690.

24 AA, 4th Ser., vol. 3, p. 502.

25 AA, 4th Ser., vol. 1, p. 913-916; AA, 4th Ser., vol. 1, p. 1158-1159; AA, 4th Ser., vol. 3, p. 99-100.
} 
argued, non-associators paved the way for tyranny. The patriots were convinced that tyranny was the logical result of the limitation of their liberty. In various associations the colonists stressed their determination not to be suppressed by the mother country. The fear of becoming completely dependent on Great Britain was kindled by members of the colonial elite. In order to further fuel the anti-British sentiment within the population, they claimed that the acts of the British parliament were part of a greater scheme aimed at enslaving the colonies. Such conspiracy theories were dispersed also by the associations. A document from Darien, Georgia, written in January 1775 refers to the British acts as a "system [...] calculated for enslaving the Colonies"26. An association in Pennsylvania called the policy of the British government "a system of tyranny and oppression"27. After the beginning of hostilities between the colonies and the mother country, the patriots felt confirmed in their judgment that Great Britain intended to subjugate the colonists. Associations that were written after the incidents at Lexington and Concord often contained the assurance that the associators were "resolved never to become slaves"28. Some texts used even stronger formulations. The association of the Fairfield Committee in Connecticut mentioned the "Ministerial Troops sent into this Country to dragoon us into slavery" ${ }^{29}$. The patriots associated "to exert ourselves in every manly, prudent, and effectual measure in concert with our brethren throughout this Continent, in opposition to every lawless attempt that may be made by our unnatural enemies to deprive us of our liberties, and subject us to a state of slavery, choosing rather to die freemen than live in a state of servile subjection to any man or body of people on the face of the earth." 30

Closely linked to the term "liberty" was the right of the British subjects to the protection of their personal property. The connection of the two concepts was rooted in eighteenth-century English political thought and can be found particularly in the works of John Locke. According to contemporary understanding property was the prerequisite for the individual's personal liberty, the civil liberty. Only persons who had property of their own were independent in their decisions. Consequently, only freeholders were entitled to vote. If the protection of liberty and property was not guaranteed by law, the subjects were prone to fall victim to the monarch's arbitrary use of power and, as a result, were in danger of losing their political liberty as well. Many of the colonists' ancestors had experienced such a limitation of their rights during the Stuart era, when it had been attempted to erect an absolute monarchy in England.

\footnotetext{
${ }^{26} \mathrm{AA}, 4^{\text {th }}$ Ser., vol. 1, p. 1136-1137.

${ }^{27} \mathrm{AA}$, 4th Ser., vol. 2, p. 615-616.

${ }^{28} \mathrm{AA}$, 4th Ser., vol. 3, p. 681-620; SAUNDERS (ed.), Colonial Records of North Carolina, vol. 10, p. 61-62; AA, $4^{\text {th }}$ Ser., vol. 2, p. 1551-1552.

${ }^{29}$ AA, $4^{\text {th }}$ Ser., vol. 3, p. 141-143.

30 Ibid.
} 
Quite a few had left the mother country precisely because of this threat to their personal and political liberty. For the inhabitants of the British colonies in North America the close connection between liberty and property was as natural as the relation between tyranny and poverty. It was not by coincidence that the patriotic resistance movement Sons of Liberty used "Liberty and Property" as their slogan. ${ }^{31}$

The colonists' harsh reaction to the duties and taxes raised by Great Britain can only be understood in this context. The laws passed by the British Parliament were strong infringements of the American subjects' right to property and thus resulted in a limitation of the colonists' liberty. Various associations stressed the illegal character of the British duties. In order to justify their demands the authors of the North Carolina Association explicitly referred to the property rights granted by the Magna Charta to every subject of the English crown. ${ }^{32}$

Often the associations mentioned the right to personal property in connection with other civil rights. Several documents stated that the purpose of the association was "the preservation of peace and good order, and the safety of individuals, and private property"33. The authors of the Maryland Association founded in July 1775 accused the British Parliament of destroying "the essential securities for the lives, liberties, and properties of the subjects in the United Colonies"34. Associations that were written after August 1775 only rarely used the term property in the context of the British civil rights. In fact, in various documents the word "property" was replaced by the term "fortunes". By using this diction the colonists apparently attempted to dissociate themselves to some extent terminologically from British legal tradition. For instance, the associators of the South Carolina Association founded in June 1775 declared that they were ready "to sacrifice [their] lives and fortunes to secure her [the Country's] freedom and safety"35. The concept of property thus was used to emphasize the colonists' determination to put at stake all their possessions, and even their lives, in order to defend the liberty of America. In the course of the intensifying conflict with the mother country, the concept of property thus changed from a term

\footnotetext{
31 See Michael Kammen, Spheres of Liberty. Changing Perceptions of Liberty in American Culture. Madison, WI 1986, p. 27.

32 See AA, $4^{\text {th }}$ Ser., vol. 1, p. 734-737.

33 AA, $4^{\text {th }}$ Ser., vol. 1, p. 1136-1137; AA, $4^{\text {th }}$ Ser., vol. 3, p. 581-620; AA, $4^{\text {th }}$ Ser., vol. 2, p. 505; AA, $4^{\text {th }}$ Ser., vol. 2, p. 1030; AA, $4^{\text {th }}$ Ser., vol. 2, p. 1551-1552; SAUNDERS (ed.), Colonial Records of North Carolina, vol. 10, p. 61-62.

34 AA, 4th Ser., vol. 3, p. 131-132.

35 AA, 4th Ser., vol. 2, p. 897. Similar formulations can be found in the following documents: AA, $4^{\text {th }}$ Ser., vol. 3, p. 99-100 (“...do solemnly engage to...risk our lives and fortunes, in maintaining the freedom of our Country..."); AA, 4th Ser., vol. 5, p. 1410 ("We...engage... at the risk of our lives and fortunes, to defend ...the United American Colonies...”); AA, 4th Ser., vol. 5, p. 873-912 (“...we will... at the risk of our lives and fortunes...oppose the hostile proceedings of the British Fleets and Armies...”).
} 
originally embedded in British law to a word symbolizing the colonists' reason to fight the mother country.

Other keywords the patriots frequently used in their association documents were "virtue", "honor" and "religion". These terms represented values that had always played a vital role in the self-image of the North American colonists. The emigrants' notion of having left the decadent and ungodly "old world" to found a new and pious society in the "new world" was quite common. Judging from the British attitude towards the colonies in the 1760s and 1770s, the Americans felt confirmed in their conviction that they morally prevailed over the "old world," since they led virtuous, honorable and godly lives, while the British completely disregarded these values.

This justification of their resistance based on moral considerations the colonists expressed also in their associations. The members of the Georgia Association founded in January 1775 declared, for instance, that they associated "under the sacred ties of virtue, honour, and love of our country"36. Similar formulations can be found in various other documents. ${ }^{37}$ In some cases the word "virtue" was either replaced by "religion" 38 , or was completely omitted. ${ }^{39}$ The members of an association in Bute County, North Carolina, promise each other support and help "under all the Tyes of Virtue and humanity" 40 . Especially the term "virtue" gained more and more importance in the course of the conflict with the mother country. "Virtue" became the touchstone of the right conduct and the correct attitude. In the Westmoreland County Association it says, for instance:

"...it is therefore become the indispensable duty of every American, of every man who has any publick virtue or love for his Country ... to resist and oppose the execution of [the system of tyranny and oppression]"41

Virtue also served as a means of differentiation from the British. John Murrin correctly notes in this context:

"To [the patriots] centralization meant a severe challenge to liberty, a threat to the Revolution itself. Yet all patriots understood that, unless they could unite and fight together effectively,

\footnotetext{
${ }^{36} \mathrm{AA}, 4^{\text {th }}$ Ser., vol. 1, p. $1158-1160$.

${ }^{37}$ See AA, $4^{\text {th }}$ Ser., vol. 1, p. 913-916; AA, $4^{\text {th }}$ Ser., vol. 2, p. 690; AA, 4th Ser., vol. 2, p. 859-861; AA, $4^{\text {th }}$ Ser., vol. 2, p. 1030.

38 See AA, 4th Ser., vol. 2, p. 505; AA, 4th Ser., vol. 2, p. 897; SAunders (ed.), Colonial Records of North Carolina, vol. 10, p. 61-62; AA, $4^{\text {th }}$ Ser., vol. 2, p. 1551-1552; AA, 4th Ser., vol. 3, p. 99-100.

39 See AA, $4^{\text {th }}$ Ser., vol. 1, p. 686-690; AA, 4th Ser., vol. 1, p. 1136-1137.

${ }^{40}$ SAUnders (ed.), Colonial Records of North Carolina, vol. 9, p. 1104-1105.

${ }^{41} \mathrm{AA}, 4^{\text {th }}$ Ser., vol. 2, p. 615-616.
} 
they would lose the war. Their early answer to this dilemma was virtue. Americans had it; the British had lost it."'42

\section{4. "His Majesty's loyal subjects" or "friends of American Liberty": The Patriots' Self- Conception}

When the First Continental Congress convened in Philadelphia in September 1774, probably none of the delegates present could imagine that, only two years later, the colonies would unanimously declare their independence from Great Britain. Although a majority of the delegates considered the adoption of a strict boycott of British goods necessary for putting pressure on the British Government and Parliament, these measures were clearly not directed against the English people or the king. The colonists continued to consider themselves subjects of the English crown. The notion of being part of an empire that was thought to have the most liberal system of government in the entire western world filled the inhabitants of the North American colonies with pride and to some extent led to a feeling of common identity. " [] $\mathrm{t}$ is the duty, and will be the endeavour of us as British American, to transmit this happy Constitution to posterity" 43 , it says in the association of the North Carolina Convention of August 1774. Well into the year 1775 the majority of Americans, no matter if they were patriots or loyalists, did not question the fact that the colonies were part of the British Empire. Until then, the seeds of conflict between revolutionaries and Tories were confined to questions of constitutional reform and the validity as well as importance of the constitutional rights. It was not before midyear 1775, when it became obvious to the colonists that their boycott measures did not have the intended effect and that the mother country was not resolved to give in, that the patriots altered their attitude. From then on they did not only turn against the British Parliament and Government, but also dissociated themselves from their British roots and the traditional bonds linking them to Great Britain. Instead, the American component of their self-perception gained importance.

This change can clearly be traced by looking at the association documents written during that particular time period. In the early associations the patriots took great care to prove the legitimacy of their demands. They used formulations like "just rights" 44 or "rights of Englishmen" 45 . The measures of resistance were agreed upon, as the

\footnotetext{
42 John M. MurRIN, A Roof Without Walls. The Dilemma of American National Identity. In: Richard BeEman, Stephen Botein, Edward C. CARTER (eds.), Beyond Confederation. Origins of the Constitution and American National Identity. Chapel Hill, NC/London 1987, p. 333-348, p. 342-343.

${ }^{43}$ AA, $4^{\text {th }}$ Ser., vol. 1, p. 734-737.

44 AA, $4^{\text {th }}$ Ser., vol. 1, p. 350-351; AA, $4^{\text {th }}$ Ser., vol. 1, p. 1145-1146; AA, $4^{\text {th }}$ Ser., vol. 2, p. 615-616.

45 AA, $4^{\text {th }}$ Ser., vol. 1, p. 734-737.
} 
authors of one association put it, "for the purpose of preserving [the British] Constitution" 46 . The authors of the North Carolina Association argued on a similar line, when they referred to the Magna Charta in order to state the legitimacy of their demand for the procedure of trial by jury. ${ }^{47}$ In many of these early documents the colonists stressed that they intended to continue the boycott of the British commerce only until reconciliation with the mother country on the basis of constitutional principles had been accomplished. ${ }^{48}$ The colonists wanted to make it clear that their demands did not leave the frame of British legal tradition and that they did not in any way intend to question the authority of King George III. In various associations written in 1774 the colonists called themselves "his Majesty's dutiful and loyal subjects"49 or "his Majesty's American Subjects" 50 . Although these phrases do not identically appear in later documents, yet similar expressions of loyalty towards the British crown in associations that were written in the first half of the year 1775 can be found. "[W]e sincerely profess ourselves to be liege subjects of King George the Third"51, it says in an association founded in Connecticut in April 1775. The associators of Westmoreland County in Pennsylvania assure the king of their loyalty to the crown:

"Possessed with the most unshaken loyalty and fidelity to His Majesty, King George the Third, whom we acknowledge to be our lawful and rightful King, and who we wish may long be the beloved Sovereign of a free and happy people throughout the whole British Empire; we declare to the world, that we do not mean by this Association to deviate from that loyalty which we hold it our bounden duty to observe..." 52

The members of an association in Pitt County, North Carolina, declare their devotion not only to the king, but to the whole house of Hanover:

"...we will pay all due allegiance to his Majesty King George the Third and endeavour to continue the succession of his crown in the Illustrious House of Hanover as by law established..." "53

\footnotetext{
${ }^{46}$ AA, $4^{\text {th }}$ Ser., vol. 3, p. 581-620. Similar formulations can be found in the following documents: AA, $4^{\text {th }}$ Ser., vol. 2, p. 505 (“...for the purposes of preserving and fixing our Constitution on a permanent basis");AA, 4th Ser., vol. 2, p. 690 ("...for defending our Constitution and preserving the same inviolate");AA, 4th Ser., vol. 2, p. 1551-1552 (“...for the purpose of preserving our Constitution”).

47 See AA, $4^{\text {th }}$ Ser., vol. 1, p. 734-737.

48 AA, 4th Ser., vol. 1, p. 1136-1137; AA, 4th Ser., vol. 3, p. 581-620; AA, 4th Ser., vol. 2, p. 505; AA, 4th Ser., vol. 2, p. 897; AA, $4^{\text {th }}$ Ser., vol. 2, p. 1551-1552; AA, $4^{\text {th }}$ Ser., vol. 3, p. 99-100.

${ }^{49}$ AA, $4^{\text {th }}$ Ser., vol. 1, p. 350-351; AA, $4^{\text {th }}$ Ser., vol. 1, p. 686-690; AA, $4^{\text {th }}$ Ser., vol. 1, p. 734-737; AA, $4^{\text {th }}$ Ser., vol. 1, p. 913-916.

50 AA, $4^{\text {th }}$ Ser., vol. 1, p. 686-690; AA, $4^{\text {th }}$ Ser., vol. 1, p. 913-916.

51 AA, $4^{\text {th }}$ Ser., vol. 2, p. 1135.

${ }^{5}$ AA, $4^{\text {th }}$ Ser., vol. 2, p. 615-616.

${ }^{53}$ SAUnders (ed.), Colonial Records of North Carolina, vol. 10, p. 61-62.
} 
After July 1775 the associations no longer contained such pledges of allegiance to the king and only rarely made any references to the British constitution. In contrast, the word "American" gradually became a cornerstone of the colonists' self-conception. This development of an American conscience, of a feeling of belonging together, was a slow process. It is not possible to determine a precise point of time at which the colonists primarily felt as Americans and not as Virginians, Pennsylvanians, or as subjects of the British crown. The words "America" and "American" were frequently used, already in the early associations. At this stage they were geographical terms, however. "America" meant the continent America, and "Americans" simply were the inhabitants of this continent. Consequently, when referring to themselves the colonists used expressions like "inhabitants of British America" 54 or "his Majesty's Subjects in North America"55. However, already at this early stage, there were formulations hinting at a meaning that went beyond the simple geographical connotation. In various associations the colonists demanded "redress of American grievances" 56 . The North Carolina Association of August 1774 already mentioned particular "rights of Americans" 57 , even though the authors expressed their "most sacred respect for the British constitution" 58 . In the associations that were written after spring 1775, the colonists no longer demanded their "constitutional rights", but mentioned the "rights of the American Colonies" 59 , "the rights and liberties of America" 60 , or "the rights and privileges of America"61. There is no increase in the frequency of such phrases in the course of the year 1775. If, nevertheless, there is a strong impression that the American component in the colonists' consciousness and self-perception gradually became more significant, it is because the expressions of loyalty toward the king as well as the references to the British constitution became increasingly rare and eventually ceased to appear.

A clearer sign of a growing American self-conception can be detected when looking at the colonists' feeling of community and their sense of solidarity for each other beyond colony borders. While at first the inhabitants' close bondage to their respective colony was prevalent, the colonists' primary reference point gradually moved to a feeling of togetherness and a sense of community that did not stop at colony borders and finally culminated in the political union of all thirteen colonies in 1776 . In the

\footnotetext{
54 AA, 4th Ser., vol. 1, p. 350-351.

55 AA, 4th Ser., vol. 1, p. 913-916.

56 AA, 4th Ser., vol. 1, p. 350-351; AA, 4th Ser., vol. 1, p. 686-690; AA, 4th Ser., vol. 1, p. 734-737; I, 11581160 .

57 AA, 4th Ser., vol. 1, p. 734-737.

58 Ibid.

59 AA, 4th Ser., vol. 1, p. 1238-1239.

${ }^{60}$ AA, 4th Ser., vol. 3, p. 581-620; AA, 4th Ser., vol. 2, p. 505; AA, 4th Ser., vol. 2, p. 1551-1552.

${ }^{61} \mathrm{AA}, 4^{\text {th }}$ Ser., vol. 2, p. 690; SAUNDERS (ed.), Colonial Records of North Carolina, vol. 10, p. 61-62.
} 
association passed by the delegates of Virginia in August 1774, for instance, the single colony still is the superior identification unit for the representatives. Although there already are phrases like "his Majesty's American subjects" 62 or "redress of American grievances"63, the references to Virginia clearly prevail. When the authors call Virginia "his [Majesty's] ancient Colony"64, such a wording expresses their pride to live not just in any colony but in this most ancient of all the British colonies in North America. In the eighth article "well-wishers of this Colony"65 are differentiated from "persons [...] inimical to this country" 66. This limitation of loyalty to "colony" or "country" was replaced by the term "American Liberty" in later association documents. In the Maryland Association written in July 1775, "America" already was the primary reference unit for the colonists:

"... [we] solemnly engage and pledge ourselves to each other, and America, that we will, to the utmost of our power, promote and support the present opposition..." "67

While this increase in importance of the colonists' consciousness of being Americans rather than British appeared implicitly in most cases, there are examples where an American identity was explicitly promoted. In this respect, the Pennsylvania Committee of Safety provides us with a vivid example with its list of rules formulated for putting into action the Military Association of the colony:

"All national distinctions in dress or name to be avoided, it being proper that we should now be united, in this General Association for defending our liberties and properties, under the sole denomination of American." 68

A similar process can be found in connection with the declarations of solidarity contained in the associations, regarding the inhabitants of Boston and Massachusetts Bay whose liberties had been restricted by the Coercive Acts. While the patriots of other colonies in the beginning usually only mentioned their "fellow-subjects in the town of Boston" 69 or simply the "inhabitants of the Massachusetts Province" 70 , an association of East Greenwich, Rhode Island, used the expression "our brethren" 71 for the in-

\footnotetext{
62 AA, 4th Ser., vol. 1, p. 686-690.

63 Ibid.

64 Ibid.

65 Ibid.

66 Ibid.

${ }^{67}$ AA, 4th Ser., vol. 3, p. 131-132.

68 AA, 4th Ser., vol. 3, p. 1802-1810.

${ }^{69} \mathrm{AA}, 4^{\text {th }}$ Ser., vol. 1, p. 686-690.

70 AA, $4^{\text {th }}$ Ser., vol. 1, p. 734-737.

71 John Russell BARTLETT (ed.), Records of the Colony of Rhode Island and Providence Plantations in New England, vol. 7: 1770-1776. New York 1968 (Repr. ed. New York 1856-1865), p. 303.
} 
habitants of Massachusetts Bay. This term which expressed the strong connection that the colonists felt with the Bostonians was also used by associations founded in North Carolina. ${ }^{72}$

More and more colonists were convinced that they could only be successful in their struggle against Great Britain, if they formed an inter-colonial union. The demand for a stronger cooperation of the colonists had been articulated already in the summer of 1774. It had led to the convocation of the First Continental Congress and to the passing of the Continental Association. Although this convention primarily focused on a political cooperation, the Congress definitely had an identity-building effect also in social respects which the patriots clearly acknowledged in their associations. In virtually all the documents written between October 1774 and the spring of 1776 the authors referred to the congress in Philadelphia. In various associations the subscribers not only agreed to abide by the regulations of the Continental Association but also to observe all following directions of the Continental Congress. ${ }^{73}$ While most documents simply spoke of the "General Congress" or the "Continental Congress", the authors of the Darien Association in Georgia referred to it as the "Grand American Congress" 74 and expressed their gratitude and their respect for the work of the Congress in an effusive manner:

"We thank [the delegates] for their sage counsel and advice, and most heartily and cheerfully accede to the Association entered into by them, as the wisest and most moderate measure that could be adopted in our present circumstances..." 75

In addition, the Congress was termed "august Assembly"76 as well as "wise, patriotick, and truly honourable" 77 . Since Georgia had declined to participate in the Philadelphia convention, the Darien associators apparently considered it necessary to express their sympathy for the inter-colonial meeting in a particularly emphatic form. By using such expressions the authors not only tried to elucidate the importance of the Continental Congress to other inhabitants of Georgia, but also wanted to demonstrate to the rest of the colonies that there did exist a patriotic movement also in Georgia which was resolved to join into the resistance measures against the mother country.

\footnotetext{
72 See SAunders (ed.), Colonial Records of North Carolina, vol. 9, p. 1104-1105; AA, 4th Ser., vol. 3, p. 99-100.

73 See AA, $4^{\text {th }}$ Ser., vol. 3, p. 581-620; AA, $4^{\text {th }}$ Ser., vol. 2, p. 505; AA, $4^{\text {th }}$ Ser., vol. 2, p. 690; SAUNDERS (ed.), Colonial Records of North Carolina, vol. 10, p. 61-62; AA, 4th Ser., vol. 2, p. 1551-1552; AA, $4^{\text {th }}$ Ser., vol. 2, p. 1659; AA, $4^{\text {th }}$ Ser., vol. 4, p. 858.

${ }^{74}$ AA, $4^{\text {th }}$ Ser., vol. 1, p. 1136-1137.

${ }^{75}$ Ibid.

${ }^{76}$ Ibid.

77 Ibid.
} 
The idea that a permanent securing of the Americans' rights and liberties could only be obtained by forming an association that explicitly included members of all classes in all colonies and was not limited to the elites of the respective colonies, was not propagated in the association documents until the spring of 1775 . The inhabitants of Newark, New Jersey, expressed their opinion "that the very existence of the rights and liberties of America can, under God, subsist on no other basis than the most animated and perfect union of its inhabitants"78. Similar phrases can also be found in other associations formed in the summer of 1775. The idea of constituting a union with the other colonies gained more and more importance. In the Maryland Association dating from July 1775 the colonies were for the first time called "United Colonies"79 - an expression that was used more frequently in later documents, often in connection with the adjective "American". ${ }^{80}$ With the exception of an association in Fairfield, Connecticut, where the authors spoke of the "United English Colonies", 81 other associations written after July 1775 usually used the terms "United Colonies" 82 or "United American Colonies" 83 for the thirteen colonies. An association founded in Connecticut in October 1775 showed that the "United Colonies" to some extent were already viewed as a fixed entity:

\section{"[W] e...will to the utmost of our power, in our several places, assist in carrying into execution every measures of the said United Colonies, that have or shall be formed and come into for their common safety..." "84}

The mainspring of the union of the colonies and their inhabitants was the Common Cause, the joint effort of the Americans to secure their rights and liberties. This awareness of a common aim first appeared in connection with the Coercive Acts in Boston. "[T] he cause in which they [the inhabitants of Boston] now suffer is the cause of every honest American"85, it said in the North Carolina Association founded in August 1774. Besides the expression "common cause" 86 the authors of later associa-

\footnotetext{
78 AA, 4th Ser., vol. 2, p. 505.

${ }^{79} \mathrm{AA}, 4^{\text {th }}$ Ser., vol. 3, p. 131-132.

80 See AA, 4th Ser., vol. 2, p. 690 (“...the preservation of the rights and privileges of America depends, under God, on the firm union of its inhabitants"); SAUNDERS (ed.), Colonial Records of North Carolina, vol. 10, p. 61-62 ("...the preservation of [the most valuable Liberties and privileges of America] Depends on a firm union of the Inhabitants"); AA, $4^{\text {th }}$ Ser., vol. 2, p. 1551-1552 (“...the salvation of the rights and liberties of America depend, under God, on the firm union of the inhabitants...”).

81 AA, 4th Ser., vol. 3, p. 141-143.

82 AA, 4th Ser., vol. 3, p. 1026-1027.

83 AA, 4th Ser., vol. 3, p. 1026-1027; AA, 4th Ser., vol. 5, p. 1410; AA, 4th Ser., vol. 5, p. 873-912.

${ }^{84}$ AA, 4th Ser., vol. 3, p. 1026-1027.

85 AA, 4th Ser., vol. 1, p. 734-737.

86 AA, 4th Ser., vol. 1, p. 1238-1239; AA, 4th Ser., vol. 2, p. 505; AA, $4^{\text {th }}$ Ser., vol. 4, p. 858.
} 
tions also used phrases like "cause of American freedom"87, "cause of America"88, or simply "the cause" 89 . For the sake of this common aim the patriots were resolved to set aside personal needs and, if necessary, to shoulder any difficulties that might arise. The members of an association of Philadelphia butchers, for instance, were willing "cheerfully to sacrifice every inferiour consideration of private interest or convenience." 90 In a document from Westmoreland County, Pennsylvania, the associators declared that they were inclined "cheerfully to submit to military discipline" 91 in order to offer resistance to the British troops.

\section{5. "Wicked ministers" and "beloved sovereign": How the Patriots Presented Their Adver- saries}

\section{Great Britain}

As has already been presented above, the colonists took great care to prevent their resistance against the laws passed by the British Parliament from being interpreted as a general revolt against the mother country. The fact that the American patriots vehemently turned against the British course of action did not mean that they questioned the legitimacy of the British authority over the North American colonies.

This attitude is clearly reflected in the association documents written between the fall of 1774 and the summer of 1775 . In various cases the authors explicitly distinguished between the king and the English population on the one hand and the British parliament and government on the other. Time and again the texts show the colonists' eagerness not to be suspected of rebellion against monarchy. The authors of the North Carolina Association of August 1774, for instance, stressed that "his Majesty King George the Third is lawful and rightful King of Great Britain" 92 and that the associators were "resolved to maintain the succession of the House of Hanover"93. In other documents the colonists assured the monarch of their "loyalty"94 or "allegiance" 95 . The members of an association in Westmoreland County, Pennsylvania, expressed their hope that George the Third "may long be the beloved sovereign of a

\footnotetext{
${ }^{87}$ AA, 4th Ser., vol. 1, p. 1210.

88 AA, 4th Ser., vol. 5, p. 873-912.

${ }^{89} \mathrm{AA}, 4^{\text {th }}$ Ser., vol. 3, p. $141-132$.

90 AA, 4th Ser., vol. 1, p. 1050-1051.

${ }^{91} \mathrm{AA}, 4^{\text {th }}$ Ser., vol. 2, p. 615-616.

92 AA, $4^{\text {th }}$ Ser., vol. 1, p. 734-737.

${ }^{93}$ Ibid.

${ }^{94}$ BARTLETT (ed.), Records of the Colony of Rhode Island, vol. 7, p. 303.

${ }^{95} \mathrm{AA}, 4^{\text {th }}$ Ser., vol. 1, p. $913-916$.
} 
free and happy people throughout the whole British Empire" 96 . In order to be able to offer resistance to the British policy regarding the colonies without being automatically labeled enemies of the British crown, the colonists proved to be quite resourceful: They declared that the monarch was falsely or insufficiently informed by his "wicked ministers" 97 and that therefore he was not responsible for the doings of government and parliament. In an association from East Greenwich, Rhode Island, the British Prime Minister is called "the most determined foe to royalty"

In a similarly positive manner the colonists tried to present their relationship to the British subjects in England who were the ones that suffered most from the American boycott measures. Especially the English merchants and manufacturers strongly felt the effects of the limitations of commerce and consumption fixed in the Continental Association and had to sustain significant losses. In various associations, the patriots courted their fellow-subjects' understanding. The authors of the Virginia Association of August 1774, for instance, stressed their "regard and affection for all our friends and fellow-subjects in Great Britain and elsewhere"99. Furthermore, they expressed their hope that the English people would recognize the necessity of the Americans' way of proceeding and that they would not blame the colonists for the consequences caused by the boycott:

"If, by the measures adopted, some unhappy consequences and inconveniences should be derived to our fellow-subjects, whom we wish not to injure in the smallest degree, we hope, and flatter ourselves, that they will impute them to their real cause, the hard necessity to which we are driven." 100

As careful and friendly as the patriots showed themselves towards the king and the British population as irreconcilable was their rhetoric regarding parliament and cabinet. In this context one can clearly detect a growing aggravation in the diction used in the associations between May 1774 and August 1775. The documents from Virginia and North Carolina written in May and August 1774 merely called the laws passed by the British Parliament "illegal"101 and "unconstitutional"102. Although the colonists accused the legislative of "arbitrary rule" 103 , they presented their protests in a relatively

\footnotetext{
${ }^{96} \mathrm{AA}$, 4th Ser., vol. 2, p. 615-616.

${ }^{97}$ AA, $4^{\text {th }}$ Ser., vol. 1, p. 913-916; AA, $4^{\text {th }}$ Ser., vol. 2, p. 615-616; AA, $4^{\text {th }}$ Ser., vol. 2, p. 897; SAUNDERS (ed.), Colonial Records of North Carolina, vol. 10, p. 61-62; AA, 4th Ser., vol. 3, p. 141-143.

${ }_{98}$ BARTLETT (ed.), Records of the Colony of Rhode Island, vol. 7, p. 303.

${ }_{99}$ AA, $4^{\text {th }}$ Ser., vol. 1, p. 686-690. Similar formulations can be found in the following documents: AA, $4^{\text {th }}$ Ser., vol. 1, p. 734-737; AA, 4th Ser., vol. 1, p. 913-916; AA, 4th Ser., vol. 1, p. 1136-1137.

100 AA, 4th Ser., vol. 1, p. 686-690.

101 AA, $4^{\text {th }}$ Ser., vol. 1, p. 734-737.

102 AA, $4^{\text {th }}$ Ser., vol. 1, p. 350-351; AA, $4^{\text {th }}$ Ser., vol. 1, p. 686-690.

103 See AA, $4^{\text {th }}$ Ser., vol. 1 , p. $350-351$.
} 
objective manner. This rhetoric clearly shows their eagerness, on the one hand to demand their legitimate rights in an emphatic manner, while on the other to be cautious enough in their choice of words so that a friendly reconciliation with the mother country would easily be possible in case Great Britain gave in. The authors of the North Carolina Association, for instance, referred to the taxation by the mother country as "highly derogatory to the rights of a subject"104 and called the laws "a gross violation of the Grand Charter of our liberties"105. The colonists merely spoke of the taxes and duties levied by Great Britain, while the Intolerable Acts were not mentioned. Unlike later documents the North Carolina Association stated the reasons for the patriots' resistance not just on a general basis, but presented their chain of arguments in detail. "It is of the very essence of the British Constitution, that no subject should be taxed, but by his own consent, freely given by himself in person, or by his legal Representatives..."106, the authors explained at the beginning. "[A]s the British subjects resident in North America, have not, nor can have, any representation in the Parliament of Great Britain", it said in the following paragraph, "therefore any Act of Parliament imposing a tax upon them, is illegal and unconstitutional."107 From these observations the colonists concluded the necessity of the agreed measures which were comprehensively listed afterwards.

Such a justification of the Americans' way of proceeding cannot be found in later documents. Often enough the colonists had presented their position in addresses and pamphlets - without success. The British government was not amenable to their arguments. The patriots' resistance grew and at the same time the tone of the associations became more aggravated. From then on the texts primarily focused on the British actions in Massachusetts Bay, while the discussion on the British taxes and duties abated. Whereas the colonists' criticism in the early texts had been confined to the observation that the laws impeded the rights of British subjects and were therefore illegal, this attitude changed from the late summer of 1775 onwards. The choice of words in these later texts leads to the conclusion that the colonists now assumed that the Parliament acted with malicious intent. A document from East Greenwich, Rhode Island, written on August 29, 1774 described the Intolerable Acts as "cruel, malignant and worse than savage"108. In other associations the authors used adjectives like "op-

\footnotetext{
104 AA, 4th Ser., vol. 1, p. 734-737.

105 Ibid.

106 Ibid.

107 Ibid.

108 BARTLETT (ed.), Records of the Colony of Rhode Island, vol. 7, p. 303.
} 
pressive"109, "despotick"110 and "vindictive"111 in this context. A document written in Westmoreland County, Pennsylvania, even referred to the laws as "obnoxious"112.

Even more negative was the patriots' attitude toward the British government. Behind the British policy regarding the North American colonies the colonists suspected a greater scheme designed to subjugate and to enslave them. In the Continental Association it says, for instance:

"...the present unhappy Situation of our Affairs is occasioned by a ruinous System of Colony Administration, adopted by the British Ministry about the Year 1763, evidently calculated for enslaving the Colonies, and with them, the British Empire..."113

In like manner, the associators in Darien, Georgia, spoke of an "unjust system of politicks adopted by the present Ministry, to subject and enslave us..."114. An even more graphic language was used by the authors of an association in Tryon County, North Carolina. They mentioned the "hostile operations and treacherous designs now carrying on by the tools of Ministerial vengeance and despotism, for the subjugating all British America"115. In various documents the government was described as "wicked"116, "corrupt"117 or "despotick"118.

The mother country's uncompromising attitude confirmed the colonists in their assumption that the tax laws were only the beginning of a new, more restrictive colonial policy. The Americans were convinced that the government's actual aim was to force the colonies into a complete dependency on Great Britain. The incidents at Lexington and Concord in April 1775 as well as the subsequent acts of violence seemed to corroborate this theory. The colonists imagined a continuity that stretched from the beginning of the British attempts to introduce new taxes and duties to the military clashes in Massachusetts. The members of the New York Association formed on April 29, 1775, declared, for instance, that they were "greatly alarmed at the avowed design of the Ministry to raise a revenue in America, and shocked by the bloody scene

109 AA, 4th Ser., vol. 1, p. 913-916; AA, 4th Ser., vol. 1, p. 1136-1137; AA, 4th Ser., vol. 2, p. 1135; AA, 4 $4^{\text {th }}$ Ser., vol. 3, p. 581-620; AA, $4^{\text {th }}$ Ser., vol. 2, p. 505; AA, $4^{\text {th }}$ Ser., vol. 2, p. 1551-1552; AA, $4^{\text {th }}$ Ser., vol. 3, p. 141-143.

110 SAUnders (ed.), Colonial Records of North Carolina, vol. 9, p. 1104-1105; AA, 4th Ser., vol. 2, p. 505.

111 AA, 4th Ser., vol. 3, p. 131-132.

112 AA, $4^{\text {th }}$ Ser., vol. 2, p. 615-616.

113 AA, 4th Ser., vol. 1, p. 913-916.

114 AA, $4^{\text {th }}$ Ser., vol. 1, p. 1136-1137.

115 AA, 4th Ser., vol. 3, p. 99-100.

116 AA, $4^{\text {th }}$ Ser., vol. 1, p. 913-916; AA, $4^{\text {th }}$ Ser., vol. 2, p. 615-616; AA, $4^{\text {th }}$ Ser., vol. 2, p. 897; SAUNDERS (ed.), Colonial Records of North Carolina, vol. 10, p. 61sq.; AA, 4th Ser., vol. 3, p. 141-143.

117 SAUNDERS (ed.), Colonial Records of North Carolina, vol. 9, p. 1104-1105.

118 Ibid.; also in: AA, $4^{\text {th }}$ Ser., vol. 2, p. 505; AA, $4^{\text {th }}$ Ser., vol. 2, p. 897. 
now acting in the Massachusetts-Bay"119. The Fairfield Association in Connecticut referred to the soldiers sent by the mother country not as "British troops" but as "Ministerial Troops sent into this Country to dragoon us into slavery"120.

In the documents written after August 1775 similar formulations did not occur anymore. The testimonies of loyalty and affection toward the king and the English population also vanished. Instead, the colonists used more general phrases like "Great Britain" or "British Fleets and Armies"121. They ceased to distinguish between "good" and "bad" Britons. The king no longer was the "misinformed Sovereign"122, the British soldiers were not called "Ministerial Troops"123 any longer, but were referred to as "his Majesty's Troops"124.

The reasons for this sudden change in the wording of the associations are complex. One explanation is obvious, of course: On August 23, 1775, in his Proclamation of Rebellion, George the Third had officially declared the colonists to be rebels. By this proclamation he had once more turned down the Olive Branch Petition sent to him by the Continental Congress. ${ }^{125}$ At the same time he had signaled that he approved the British military actions in the colonies. Thus, to the patriots, the distinction between king and government/parliament did not make sense anymore.

Apart from stating the colonists' point of view towards Great Britain, the associations were also meant to influence the public opinion within the colonies. The testimonies of loyalty that so often appeared in the early associations were not only directed to the king, but also to the inhabitants of the North American colonies themselves. Many colonists were afraid of being suspected of participating in a revolt against monarchy. In order to set their apprehensions at rest and, nevertheless, win them over to their cause, the authors of the associations repeatedly stressed their loyalty towards the king. The more support the resistance measures against Great Britain gained in the course of the conflict with the mother country, the less important became such avowals of allegiance. After the conflict had entered the stage of military confrontations, even patriots who until then had been moderate in their views were now convinced of the necessity to defend their rights not only against the British government and parliament, but also against the British crown.

\footnotetext{
119 AA, 4th Ser., vol. 3, p. 581-620.

120 AA, 4th Ser., vol. 3, p. 141-143.

121 AA, 4th Ser., vol. 5, p. 1410; AA, 4th Ser., vol. 5, p. 873-912.

122 AA, 4th Ser., vol. 3, p. 141-143.

123 Ibid.

124 AA, 4th Ser., vol. 4, p. 858.

125 In its Olive Branch Petition from July 8, 1775, the Continental Congress again had assured the king of the colonists' loyalty and had requested of him to end the measures of suppression against the colonies.
} 
Another aspect explaining the change in the colonists' choice of words is that a peaceful reconciliation between the mother country and the colonies had become impossible after the escalation of the conflict in the early summer of 1775. From then on the Americans were at war with Great Britain. The diligence with which the colonists had avoided such formulations in their early association documents and which had been functional then in order not to complicate matters in case of a reconciliation, had now become obsolete.

\section{Loyalists}

In the course of the escalating crisis with the mother country, the colonists did not constitute a homogeneous mass. Instead, they were deeply split into patriots and loyalists. This division gained more and more importance as the conflict with the mother country wore on. From the point of view of those Americans who were fighting for "American Liberty", the loyalists were traitors in their own ranks who did not care about the defense of the colonists' freedom. Such a cleavage based on the foundation of different political positions had never before existed in the North American colonies. Although a certain degree of segmentation had always been a characteristic feature of the colonial society, these differentiations were usually based on distinct national origins, varying religious beliefs or feelings of affiliation to different colonies. In some cases the contrast between urban and rural population was significant as well. But usually, these differences did not lead to ostracism. The division along the cleavage patriots/loyalists gave the fragmentation of the colonial society an entirely new quality. By making the political position the touchstone for the evaluation of the individual, the colonists accepted the fact that the society was divided into two parts which were not able to live together peacefully. Nuances no longer existed, when it came to judging fellow citizens: There only were supporters and disapprovers of the Common Cause and the revolution.

The associations strongly contributed to deepening this cleavage in the colonial society. The patriots soon understood that their resistance against Great Britain could only be successful, if they were supported by as many colonists as possible. For this reason not only persons who publicly ignored the boycott measures were viewed as enemies, but also colonists who refused to take sides and remained neutral. Inactivity and indifference were as inconsistent with the objectives of the anti-British associations as willful violations of the regulations by avowed loyalists. Therefore various texts contained regulations determining how patriots were supposed to deal with colonists who refused to join the associations or who did not abide by the rules of the Continental Association. The Virginia Association composed in August 1774, for 
instance, laid down that the names of such persons were to be published in the newspapers. ${ }^{126}$ As to persons who violated the non-exportation agreement, it says in the document:

"...we shall hold ourselves obliged to consider such person or persons inimical to the community, and as an approver of American grievances..." "127

The Continental Association used an even harsher wording. In the eleventh article the authors called persons who disregarded the regulations of the association "foes to the rights of British America"128 and "Enemies of American Liberty"129. Especially the second expression became the current term among patriots when referring to loyalists. Some documents, for example the Georgia Association written in January 1775, literally adopted the formulations used in the Continental Association. ${ }^{130}$ In later texts the authors no longer meant by "enemies of American liberty" colonists who violated the boycott measures, but only applied this term to persons who refused to subscribe to the association. The authors of the South Carolina Association formed in June 1775 unequivocally stressed their disapprobation of non-associators:

"And we will hold all those persons inimical to the liberty of the Colonies, who shall refuse to subscribe to this Association." "131

This shifting focus on non-subscribers was caused by the fact that later associations did not list their own boycott measures. By signing the documents the associators committed themselves to accepting the Continental Association and in some cases even all regulations of the Continental Congress. Since a regulation regarding violations of the boycott measures was included in the Continental Association, the documents of associations formed on local or regional levels could omit such a rule. It is quite remarkable in this context that the expression "Enemy of American Liberty" was only used in the formal association documents and in public notices printed in newspapers. In the minutes of the Committees of Inspection and Observation or in other documents that were not meant for the public, the authors usually used the more objective term "non-associators".

Apart from the phrases mentioned above there were no further references to loyalists in the associations. Not a single document addressed them directly. Unlike the British parliament and government that were characterized by negative traits in virtu-

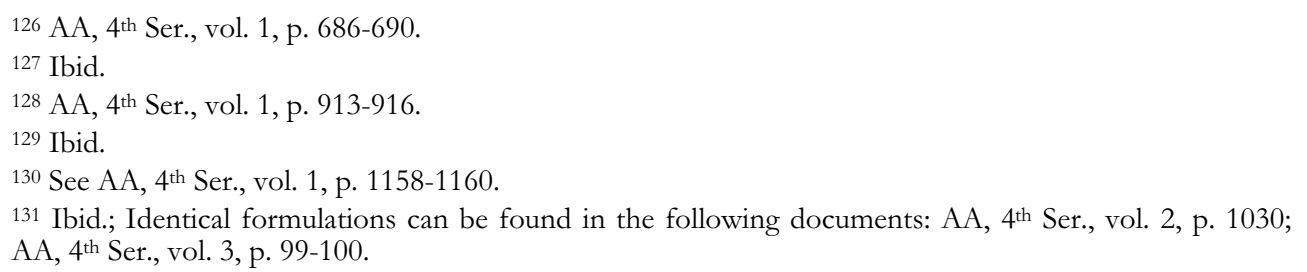


ally every single association, the loyalist colonists were spared a similar rhetoric. There certainly are various reasons for this fact: First, essential differences between the "external" enemy Great Britain and the "internal" adversaries of the patriots come to light in this context. Parliament and government were abstract entities that could not be attacked with other than rhetorical means. The loyalists, on the other hand, were individual persons who lived in close neighborhood of the patriotic colonists. Often they were personally acquainted with each other. Consequently, the patriots' uncompromising and disapproving attitude towards the loyalists became manifest rather in actions than in words. Secondly, the primary purpose of the associations was the formation of resistance against the British taxes and duties and, later on, against the British troops. By writing the associations, the patriots consequently intended to achieve two goals: One purpose was to foment the colonists' resentments against Great Britain, the other was the attempt to present the colonial population as an entity firmly united in the Common Cause. It could therefore certainly not lie in the interest of the authors of associations to further underline the division of the colonies' inhabitants into patriots and loyalists. A third aspect is that the innumerable pamphlets circulating in the colonies as well as the colonial newspapers already provided for a great deal of agitation against the enemies inside the colonies. The authors of the associations could therefore abstain from any additional campaigning against the loyalists.

\section{Associations: Mirrors and Instruments of Revolutionary Mobilization}

This analysis has shown that the association documents indeed clearly reflect the evolvement of a common American identity. The development of the language used in the associations between 1774 and 1776 vividly demonstrates the colonists' growing detachment from Great Britain. At the same time the texts depict the gradual emergence of a powerful sense of belonging together of the Americans. The bonds that had so strongly tied the inhabitants of British America to their respective colonies and to the British crown lost importance in the Americans' self-conception as they gradually became more aware of themselves and of being different from the British subjects living in England. The increasing frequency in the use of the term "American" in the associations delineates this growing self-consciousness of the colonists. The semantic change of some of the keywords, especially the word "liberty", gives proof of this development. It is not by chance that the protection of freedom and property have remained key values of US-American society up until today and are regarded as genuinely American achievements by many Americans.

The gap that had evolved - and that was gradually widening - between the colonies and their mother country formed the counterpart to the growing American selfconsciousness. Only the colonists' growing dissociation from Great Britain made it 
possible for a common American identity to gain importance. This process is clearly exhibited in the change the language used in the association documents underwent in the course of the two years. At the beginning of the conflict with the mother country the patriots were careful not to turn against Great Britain as a whole, but clearly distinguished between the actions of the government and parliament on the one hand and the king and British people on the other. As the struggle with Britain was intensifying in the summer of 1775 this distinction vanished from the associations and gave way to a more uncompromising American-centered attitude.

However, the patriotic associations not merely reflected the colonists' frame of mind, but also influenced the revolutionary movement quite actively. Associations were one of the most effective instruments of mobilization the patriots disposed of during the early years of the American Revolution. Due to their extremely high degree of inclusiveness and their wide propagation throughout the thirteen colonies the colonists' unions served as mainsprings of the American resistance against the mother country. Their mode of operation was, to a large extent, self-intensifying: The greater the number of colonists was who openly declared themselves for the common cause and signed the associations - no matter if voluntarily or because of the pressure the committees of inspection and observation put upon them - the higher was the degree of legitimacy the patriotic alliances disposed of. This larger base of support, in turn, provided the patriots with the means to increase the pressure on those colonists who had not yet agreed to join an association. This aspect has to be taken into account when looking at the change of language depicted in the documents. There can be no doubt that the authors of the associations were convinced patriots and zealous defenders of the common cause. It is not surprising that the rhetoric used in the texts reflects this attitude. To assume, however, that the "regular" associators - that is the persons who merely signed the documents - also were all fervent advocates of the revolutionary movement would certainly go too far. A great number of Americans simply bowed to the pressure of the committees and thus outwardly acted as patriots by signing the documents and abiding by the rules of the associations while at the same time they did not actually identify themselves with the common cause.

In spite of this consideration, however, the original conclusion remains valid: The patriotic associations document a substantial change in the Americans' self-perception. Even if these alterations were not deeply rooted in the colonists' consciousness right from the beginning, they certainly triggered off a process of re-orientation that was consolidated after the Declaration of Independence and paved the way for the development of an American national identity. 